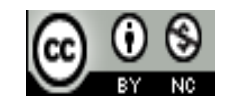

Jurnal Pendidikan Bahasa dan Sastra Indonesia is licensed under

A Creative Commons Attribution-Non Commercial 4.0 International License

\title{
Kelayakan Kebahasaan dan Isi Buku Teks Bahasa Indonesia Kelas XII Semester 1 SMA
}

\author{
Yusuf Hendrawanto ${ }^{1)}$, Mimi Mulyani ${ }^{2)}$, \\ 1. APPBIPA Jawa Tengah, Indonesia \\ E-mail:hendrawantoyusuf@gmail.com \\ 2. Universitas Negeri Semarang, Jawa Tengah, Indonesia, \\ E-mail: mimimulyadi62@gmail.com
}

\begin{abstract}
Abstrak. Buku teks Bahasa Indonesia kelas XII semester 1 masih dikeluhkan guru karena memiliki banyak kekurangan dari aspek kebahasaan dan isi. Penelitian ini bertujuan mendeskripsikan dan menganalisis kelayakan buku teks Bahasa Indonesia kelas XII semester 1 yang digunakan di SMA Islam Sudirman. Aspek kelayakan yang dinilai adalah aspek kebahasaan dan isi. Data dalam penelitian kualitatif ini dikumpulkan dengan metode simak dan cakap sedangkan untuk menganalisis data digunakan metode analisis isi. Penelitian ini menggunakan triangulasi pakar untuk menguji keabsahan data, yaitu data dihasilkan oleh peneliti, guru, dan siswa dengan mengisi kartu data berdasarkan aspek kelayakan buku teks. Hasil penelitian ini menunjukkan kelayakan aspek kebahasaan dan isi dalam buku teks tersebut. Aspek kebahasaan dan isi mendapatkan skor 50,97 dan 52,27 sehingga tergolong masih kurang layak. Kedua aspek tersebut perlu diperbaiki agar buku teks tersebut layak digunakan oleh guru dan siswa.
\end{abstract}

\section{Kata Kunci : kelayakan kebahasaan, isi buku teks, bahasa Indonesia}

\section{PENDAHULUAN}

Kurikulum di Indonesia telah mengalami beberapa kali perubahan. Kurikulum yang berlaku di Indonesia saat ini adalah Kurikulum 2013. Pada Kurikulum 2013, pembelajaran yang diterapkan adalah pembelajaran berbasis teks. Teks yang dimaksud dalam kurikulum ini tidak hanya berupa teks dalam bahasa tulis, namun juga dapat berupa bahasa lisan dan gambar. Pembelajaran berbasis teks idealnya berawal dari kegiatan memahami teks, mengolah teks, mendiskusikan teks, mengubah teks, dan diakhiri dengan memproduksi teks. Dengan berbasis teks, bahasa digunakan siswa tidak hanya sebagai sarana komunikasi, tetapi juga sarana mengembangkan kemampuan berpikir (Lestari dan Mulyani 2016:61).

Di antara kelebihan dalam Kurikulum 2013 adalah adanya buku teks pegangan siswa. Hanya saja masih terdapat kekurangan yang ditemukan dalam buku tersebut, khususnya buku teks SMA. Di antaranya adalah kekurangan dalam aspek kebahasaan. Di dalam contohcontoh teks cerpen yang disajikan, terdapat kata-kata yang kurang mendidik, yaitu terdapat kata "pelacur" dan "babi ngepet". kata-kata tersebut tidak sesuai dengan kebiasaan masyarakat karena kata-kata tersebut termasuk kata-kata tabu, berbau seks, merujuk pada sesuatu benda yang menjijikkan. Kata "kotor" dan "kasar" termasuk kata-kata tabu dan tidak lazim digunakan (Handayani, Santoso, dan Widayanti 2011:56).

Kekurangan lain juga terdapat dalam aspek materi, yaitu materi teks prosedur yang disajikan hanya berupa teks berisi petunjuk-petunjuk sederhana, tanpa dikaitkan dengan konteks pendidikan (Wijayanti, Zulaeha, dan Rustono 2015:96). Hal tersebut menyebabkan materi yang disajikan kurang mendalam karena tidak memberikan kebermaknaan bagi siswa.

Beberapa contoh kekurangan dalam aspek kebahasaan dan isi tersebut menunjukkan bahwa kelayakan buku teks masih perlu diteliti. Riyanto (2013:29) menyebutkan, setidaknya ada empat syarat yang harus dipenuhi apabila sebuah bahan ajar dikatakan baik. Pertama, cakupan materi atau isi sesuai dengan kurikulum. Kedua, penyajian materi memenuhi prinsip belajar. Ketiga, bahasa dan keterbacaan baik. Keempat. format buku atau grafika yang menarik. Empat syarat tersebut, khususnya aspek kebahasaan dan isi masih belum terpenuhi dalam buku teks Bahasa Indonesia, khususnya buku teks Bahasa Indonesia kelas XII semester 1 (2015).

Penelitian tentang kelayakan kebahasaan dan isi buku teks Bahasa Indonesia kelas XII semester 1 perlu dilakukan 
karena terdapat banyak keluhan dari guru seputar aspek kebahasaan dan isi yang masih kurang dalam buku teks tersebut. Hasil penelitian tersebut akan menunjukkan kelayakan buku teks tersebut untuk digunakan oleh guru dan siswa dalam pembelajaran di kelas. Penelitian tentang kelayakan buku teks sudah pernah dilakukan oleh peneliti dari Indonesia maupun asing. Beberapa diantaranya adalah penelitian yang dilakukan oleh Firdaus, dkk (2014), Abed dan Al-Absi (2015), Eze (2015), dan Yurtseven dan Mehtap (2016). Keempat penelitian tersebut menganalisis kelayakan buku teks yang digunakan dalam pembelajaran di kelas.

Salah satu contoh dapat dilihat dalam penelitian Abed dan Al-Absi (2015) berjudul "Content Analysis of Jordanian Elementary Textbooks during 1970-2013 as Case Study" yang menunjukkan kelayakan buku teks di Jordania selama tahun 1970-2013. Penelitian tersebut membahas tentang buku teks yang digunakan di Jordania. Metode yang digunakan adalah metode analisis isi untuk menganalisis aspek kebahasaan dan isi dalam buku teks. Hasil penelitian menunjukkan bahwa bentuk kebahasaan dan materi yang terdapat dalam buku teks perlu diperbaiki. Penelitian tersebut memiliki persamaan dengan penelitian ini, yaitu menggunakan metode analisis isi.

Penelitian yang berasal dari Indonesia dilakukan oleh Firdaus, dkk (2014). Penelitian tersebut berjudul "Analisis Kelayakan Isi Buku Teks Bahasa Indonesia Terbitan Erlangga Kelas VII SMP/MTs". Penelitian tersebut menunjukkan kualitas buku teks Bahasa Indonesia Kurikulum 2013 yang diterbitkan oleh penerbit selain Kemendikbud. Penelitian tersebut menunjukkan bahwa buku teks Bahasa Indonesia terbitan Erlangga kelas VII SMP/MTs masuk dalam kategori layak pakai. Penelitian Firdaus, dkk memiliki persamaan dengan penelitian ini karena menggunakan metode analisis isi. Perbedaan terdapat dalam aspek kelayakan dan buku teks yang dianalisis. Penelitian ini mendeskripsi dan menganalisis kelayakan buku teks kelas XII semester 1 SMA berdasarkan aspek kebahasaan dan isi.

Kelayakan kebahasaan dan isi pada buku teks Bahasa Indonesia kelas XII semester 1 (2015) sangat penting untuk diteliti. Penelitian ini menggunakan metode analisis isi. Berdasarkan uraian di atas, tujuan penelitian ini adalah mendeskripsi dan menganalisis kelayakan kebahasaan dan isi pada buku teks Bahasa Indonesia kelas XII semester 1 (2015).

\section{METODE}

Penelitian ini adalah penelitian deskriptif kualitatif. Deskriptif karena penelitian ini mengolah data dalam buku teks Bahasa Indonesia kelas XII semester 1 SMA untuk dianalisis. Kualitatif karena data yang digunakan tidak diperoleh melalui prosedur-prosedur statistik, melainkan data berasal dari dokumen dan hasil wawancara. Selanjutnya, hasil analisis tersebut akan dikonfirmasi dengan hasil wawancara dengan responden. Pendekatan teoretis yang digunakan ialah analisis isi (content analysis) dan pendekatan metodologis yang digunakan ialah pendekatan kualitatif. Weber (dalam Moleong 2007:219) menyatakan bahwa analisis isi adalah metodologi penelitian yang memanfaatkan seperangkat prosedur untuk menarik simpulan yang sahih dari sebuah buku atau dokumen. Definisi lain dari analisis isi diungkapkan oleh Kripendorff (dalam Moleong 2007:220) yang mengemukakan bahwa analisis isi adalah teknik penelitian yang digunakan untuk menarik simpulan yang replikatif dan sahih dari data atau dasar konteksnya. Jadi, analisis isi adalah analisis yang bertujuan untuk mendeskripsikan data yang kompleks.

Metode penelitian pada penelitian ini menggunakan metode analisis isi kualitatif atau ethnographic content analysis. Altheide (dalam Kriyantono 2007:247) menyebutkan bahwa analisis isi kualitatif adalah perpaduan antara analisis isi objektif dengan observasi partisipan. Istilah ethnographic content analysis mengacu kepada kegiatan yang dilakukan oleh peneliti untuk berinteraksi dengan material-material dokumentasi atau bahkan melakukan wawancara mendalam sehingga pernyataanpernyataan yang spesifik dapat diletakkan pada konteks yang tepat untuk diteliti. Jadi, setelah melakukan analisis secara objektif terhadap konten kebahasaan dan isi pada buku teks Bahasa Indonesia kelas XII semester 1 SMA terbitan Kemdikbud, peneliti membandingkan hasil analisis data primer tersebut dengan data sekunder, yaitu hasil wawancara dengan responden. Hasil yang diperoleh akan menjawab kelayakan buku teks Bahasa Indonesia kelas XII semester 1 SMA terbitan Kemendikbud.

Data primer dalam penelitian ini ialah konten kebahasaan dan isi pada buku teks Bahasa Indonesia kelas XII semester 1 SMA (2015) terbitan Kemendikbud. Data sekunder dalam penelitian ini ialah data berupa hasil wawancara dengan responden. Data ini digunakan untuk mengonfirmasi hasil data primer. Responden dalam penelitian ini adalah guru dan siswa dari SMA Islam Sudirman.

Penelitian ini menggunakan prosedur analisis isi kualitatif yang terdiri atas 12 langkah. Berikut adalah langkah-langkah metode analisis isi kualitatif (diadaptasi dari Ida 2001:163).

1. Identifikasi masalah yang akan diteliti.

2. Observasi di lapangan.

3. Menyeleksi unit analisis

4. Membuat rencana penelitian dan kategorisasi analisis.

5. Menguji rencana penelitian dengan melakukan latihan analisis.

6. Melakukan revisi terhadap rencana penelitian dan menambahkan responden sebagai sumber data.

7. Menentukan teknik pengumpulan data primer dan data sekunder.

8. Mengumpulkan data primer.

9. Analisis data.

10. Mencatat hasil analisis data.

11. Mengumpulkan dan menganalisis data sekunder

12. Mengintegrasikan semua temuan data dengan interpretasi peneliti.

Teknik pengumpulan data yang digunakan dalam penelitian ini adalah metode simak dengan teknik sadap, metode cakap atau wawancara dengan teknik pancing, teknik rekam, dan teknik cakap semuka. 
Instrumen dalam penelitian ini terbagi menjadi dua, yaitu instrumen untuk data primer dan sekunder. Pada teknik pengumpulan data dan analisis data primer, instrumen yang digunakan adalah kartu data untuk mengetahui konten kebahasaan dan isi. Instrumen dalam penelitian ini dilengkapi pula oleh pedoman wawancara untuk memperoleh data sekunder. Wawancara dilakukan terhadap guru dan siswa untuk mengonfirmasi data primer.

Data primer dikumpulkan dengan menggunakan teknik sadap. Data tersebut berupa konten kebahasaan dan isi pada buku teks Bahasa Indonesia kelas XII semester 1 SMA terbitan Kemdikbud. Data sekunder dikumpulkan dengan metode cakap. Data ini berupa hasil wawancara. Data wawancara ini diperoleh setelah melakukan wawancara terstruktur terhadap responden. Data sekunder juga dijadikan sebagai data pembanding dari data primer yang telah didapat. Hasil perbandingan tersebut untuk melihat kelayakan buku teks Bahasa Indonesia kelas XII semester 1 SMA terbitan Kemendikbud.

Keterangan kelayakan buku teks (BSNP: 2016):

$0-20 \quad=$ Kurang layak sekali

21-60 = Kurang layak

61-80 = Layak

$81-100=$ Sangat layak

\section{PEMBAHASAN}

Hasil penelitian yang akan dipaparkan meliputi kelayakan kebahasaan dan isi pada buku teks Bahasa Indonesia kelas XII semester 1 (2015).

Setiap aspek kelayakan dalam buku teks terbagi ke dalam butir-butir kelayakan yang lebih spesifik. Berikut akan disajikan hasil kelayakan buku teks kelas XII semester 1 SMA berdasarkan aspek kelayakan kebahasaan dan isi.

\section{Kelayakan Kebahasaan}

Kelayakan kebahasaan dalam buku teks Bahasa Indonesia kelas XII semester 1 (2015) disajikan dalam tabel berikut.

Tabel 1 Hasil Penilaian Kelayakan Kebahasaan dalam Buku Teks Bahasa Indonesia Kelas XII Semester 1 SMA

\begin{tabular}{|l|l|l|}
\hline No. & Kelayakan Kebahasaan & $\begin{array}{l}\text { Buku Teks } \\
\text { Bahasa } \\
\text { Indonesia } \\
\text { Kelas XII } \\
\text { Semester 1 }\end{array}$ \\
\hline 1. & $\begin{array}{l}\text { Kesesuaian dengan tingkat } \\
\text { perkembangan intelektual peserta } \\
\text { didik }\end{array}$ & 46,75 \\
\hline 2. & $\begin{array}{l}\text { Kesesuaian dengan tingkat } \\
\text { perkembangan sosial emosional } \\
\text { peserta didik }\end{array}$ & 45,1 \\
\hline 3. & Keterbacaan pesan & 47,6 \\
\hline 4. & Ketepatan bahasa & 48,5 \\
\hline 5. & Keruntutan dan keterpaduan bab & 71,25 \\
\hline
\end{tabular}

\begin{tabular}{|l|l|l|}
\hline 6. & $\begin{array}{l}\text { Keruntutan dan keterpaduan } \\
\text { paragraf }\end{array}$ & 46,67 \\
\hline Skor rata-rata & & $\mathbf{5 0 , 9 7}$ \\
\hline
\end{tabular}

Berdasarkan hasil penilaian di atas, aspek kebahasaan mendapatkan skor rata-rata 50,97 atau tergolong kurang layak. Butir kelayakan kebahasaan yang tergolong layak hanya satu, yaitu butir keruntutan dan keterpaduan bab dalam buku teks Bahasa Indonesia kelas XII semester 1 SMA sedangkan lima butir kelayakan lainnya masih tergolong kurang layak. Hasil penilaian menggunakan kartu data di atas sesuai dengan hasil wawancara kepada guru dan siswa yang menunjukkan bahwa kelayakan kebahasaan dalam buku teks tergolong kurang layak.

Contoh bentuk kebahasaan yang kurang sesuai dengan tingkat keterbacaan siswa terdapat dalam wacana di halaman 6, 25, dan 89. Ketiga wacana tersebut merupakan wacana yang diambil dari internet dan berbagai sumber. Wacana-wacana tersebut terlalu mudah dipahami siswa dan memiliki keterbacaan yang rendah. Selain itu, kalimatkalimat dalam terks tersebut terkadang sulit dipahami karena tidak jelas. Di halaman 6, wacana berjudul "Sejarah Hari Buruh" merupakan wacana wacana yang diadaptasi dari berbagai sumber sehingga tingkat keterbacaannya belum sesuai dengan tingkat keterbacaan siswa SMA. Selanjutnya di halaman 25, terdapat wacana berjudul "Peristiwa Pembentukan ASEAN" yang tingkat keterbacaannya juga belum sesuai dengan tingkat keterbacaan siswa. Berikutnya pada halaman 89 , terdapat kalimat-kalimat yang tidak jelas sehingga membuat siswa bingung dengan isi materi dan cara pengerjaan soal. Wacana di halaman 89 tersebut yang memiliki keterbacaan rendah. wacana tersebut berisi uraian materi tetapi menggunakan kalimat yang sulit dipahami oleh siswa. berdasarkan hasil analisis tersebut, seharusnya wacana yang disajikan sebagai contoh teks bukanlah wacana yang diadaptasi dari berbagai sumber, melainkan wacana yang bersumber dari buku. Bentuk kebahasaan yang masih sulit dipahami oleh siswa juga masih perlu diperbaiki.

Selain itu, pernyataan guru SMA Islam Sudirman juga menunjukkan bahwa tingkat keterbacaan wacana juga masih belum sesuai dengan tingkat keterbacaan siswa karena masih ada beberapa teks yang memiliki tingkat keterbacaan rendah maupun terlalu tinggi sehingga membuat siswa sulit untuk memahami materi yang disajikan di dalam wacana. Pendapat guru sesuai dengan hasil wawancara kepada siswa dari SMA Islam Sudirman yang menunjukkan bahwa terdapat beberapa kalimat yang sulit dipahami di dalam bacaan. Berdasarkan hasil wawancara tersebut, kekurangan yang terdapat dalam aspek kebahasaan terletak pada bentuk kebahasaan dalam buku teks yang kurang sesuai dengan tingkat ketebacaan siswa. Perbaikan yang disarankan adalah memperbaiki bentuk kebahasaan, khususnya bahasa yang digunakan untuk menjelaskan konsep materi.

Hasil analisis terhadap kelayakan kebahasaan buku teks kelas XII semester 1 yang diuraikan di atas berpedoman pada indikator dan deskripsi penilaian yang terdapat dalam Standar BSNP yang dikeluarkan oleh Pusbuk. Deskripsi dan hasil analisis yang diuraikan di atas menunjukkan bahwa 
kelayakan kebahasaan dalam buku teks kelas XII semester 1 masih tergolong kurang layak sehingga guru perlu memandu dan membantu siswa agar dapat memahami bentuk kebahasaan yang disajikan dalam buku teks, khususnya untuk memahami konsep materi dan contoh-contoh yang disajikan dalam buku teks.

\section{Kelayakan Isi}

Kelayaan isi buku teks Bahasa Indonesia kelas XII semester 1 (2015) disajikan dalam tabel berikut.

Tabel 2 Hasil Penilaian Kelayakan Isi dalam Buku Teks Bahasa Indonesia Kelas XII Semester 1 SMA

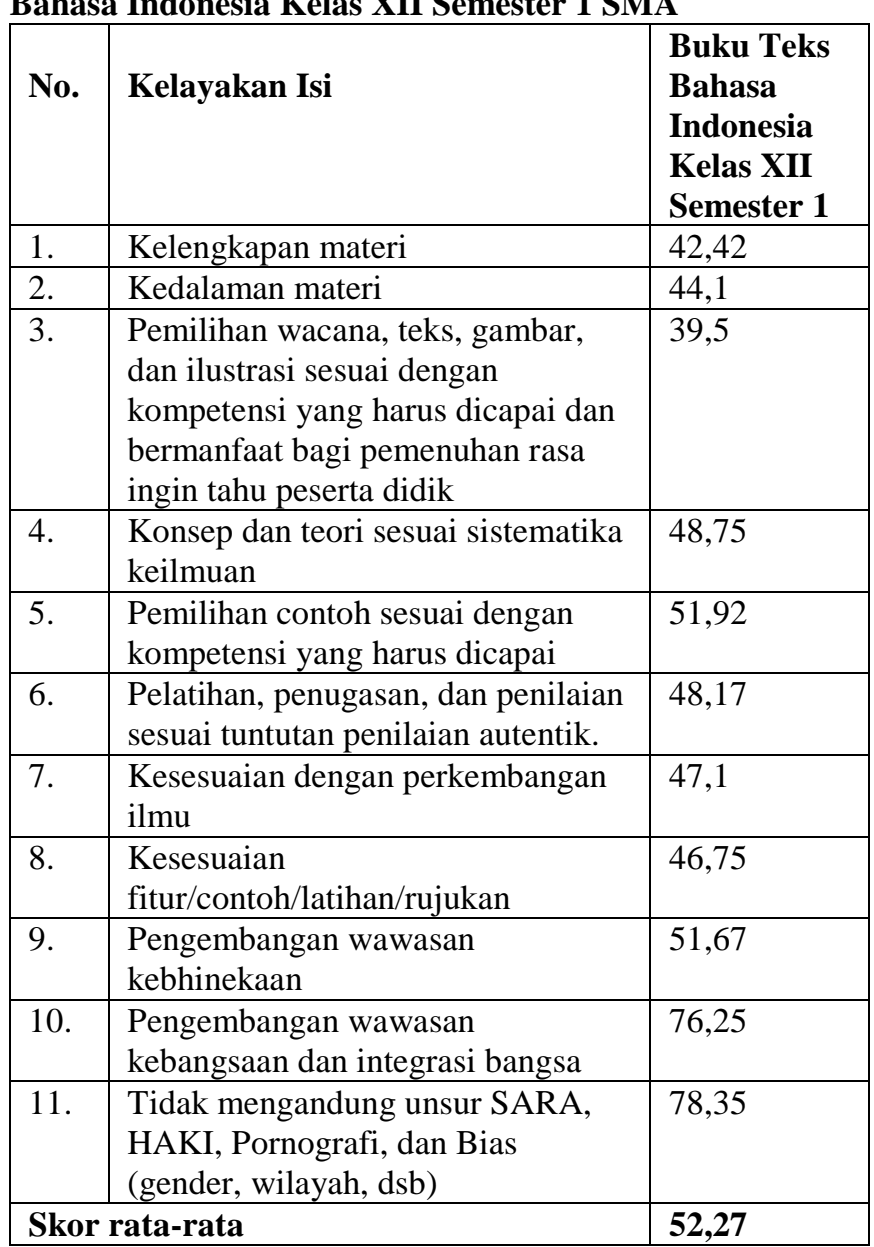

Berdasarkan hasil penilaian di atas, aspek kebahasaan mendapatkan skor rata-rata 52,27 atau tergolong kurang layak. Butir kelayakan isi yang tergolong layak hanya dua, yaitu butir pengembangan wawasan kebangsaan dan integrasi bangsa dan butir kandungan unsur SARA, HAKI, pornografi, dan bias sedangkan sembilan butir kelayakan lainnya masih tergolong kurang layak. Hasil penilaian menggunakan kartu data di atas sesuai dengan hasil wawancara kepada guru dan siswa yang menunjukkan bahwa kelayakan isi dalam buku teks Bahasa Indonesia Kelas XII semester 1 SMA tergolong kurang layak.

Salah satu contoh ketidaklengkapan materi dapat dilihat di halaman 182-183. Judul subbab di halaman tersebut adalah menyunting dan mengabstraksi teks iklan tetapi di dalam latihan soal yang disajikan, tidak ada satu soal pun yang meminta siswa untuk mengabstraksi teks iklan. Hal tersebut menunjukkan bahwa materi yang disajikan masih belum lengkap.

Selain itu, pernyataan guru SMA Islam Sudirman juga menunjukkan bahwa masih banyak materi yang belum lengkap. misalnya bagaimana cara mengabstraksi, menyunting, dan mengonversi teks di setiap bab. Selain itu, banyak materi yang hanya dijelaskan secara ringkas dan tidak disertai sumber rujukan sehingga siswa masih merasa kurang. Pendapat guru sesuai dengan hasil wawancara kepada siswa dari SMA Islam Sudirman yang menunjukkan bahwa siswa terbiasa mencari materi dari internet karena materi yang disajikan dalam buku teks masih kurang lengkap. Materi yang biasa dicari di internet adalah pengertian, contoh teks, dan cara menulis teks. Berdasarkan hasil wawancara tersebut, aspek isi masih banyak materi dalam buku teks yang masih belum lengkap. Perbaikan yang disarankan adalah melengkapi materi yang belum disajikan dalam buku teks dan melengkapi uraian materi yang dikutip dengan sumber rujukan.

Hasil analisis terhadap kelayakan isi buku teks kelas XII semester 1 yang diuraikan di atas berpedoman pada indikator dan deskripsi penilaian yang terdapat dalam Standar BSNP yang dikeluarkan oleh Pusbuk. Deskripsi dan hasil analisis yang diuraikan di atas menunjukkan bahwa kelayakan isi dalam buku teks kelas XII semester 1 masih tergolong kurang layak sehingga guru perlu mengoreksi materi yang kurang tepat, memberikan penjelasan tentang materi yang belum disajikan, serta memberikan varian contoh teks kepada para siswa.

\section{SIMPULAN}

Berdasarkan hasil penilaian yang telah diuraikan di atas, dapat disimpulkan sebagai berikut.

Hasil analisis kelayakan buku teks menggunakan Standar BSNP menunjukkan kelayakan kebahasaan dan isi pada buku teks Bahasa Indonesia kelas XII semester 1 SMA. Aspek kebahasaan dan isi dalam buku teks mendapatkan skor 50,97 dan 52,27 sehingga kedua aspek tersebut masih tergolong kurang layak. Hasil tersebut diperoleh dari hasil penilaian peneliti, guru, dan siswa (SMA Islam Sudirman) dalam kartu data.

Hasil temuan selanjutnya diperoleh dari hasil wawancara dengan guru dan siswa di SMA Islam Sudirman yang menunjukkan bahwa buku teks Bahasa Indonesia kelas XII semester 1 SMA memiliki kelebihan dan kekurangan. Kelebihan buku teks adalah materi yang disajikan merupakan acuan materi untuk Kurikulum 2013 sedangkan kekurangan dalam buku teks adalah (1) bentuk kebahasaan dalam buku teks sulit dipahami oleh siswa, (2) materi yang disajikan masih belum lengkap.

Implikasi dalam penelitian ini menunjukkan bahwa kelayakan kebahasaan dan isi merupakan dua aspek penting yang harus terpenuhi untuk dapat meningkatkan kualitas 
kelayakan buku teks sehingga layak untuk digunakan oleh siswa dan guru.

Peneliti mengharapkan agar hasil penelitian ini dapat mendorong guru dan peneliti lain untuk melakukan penelitian lebih lanjut tentang kelayakan buku teks dari berbagai jenjang. Adanya ruang lingkup yang luas terkait kelayakan buku teks membuat penelitian lanjutan bukanlah hal yang mustahil. Dengan adanya penelitian ini, diharapkan guru dapat menganalisis kelayakan buku teks terlebih dahulu sebelum digunakan sehingga dapat mengetahui kelebihan dan kekurangan buku teks tersebut. Selanjutnya, guru dapat memaksimalkan materi dalam buku teks dengan melengkapinya dari sumber lain atau mengembangkannya dengan membuat bahan ajar secara mandiri.

Peneliti berharap buku teks K-13 terbitan Kemendikbud dapat dikaji lebih lanjut dikarenakan masih banyak aspek dalam buku teks yang masih dapat dikaji dengan lebih mendalam. Dengan demikian dapat memperluas dan memperdalam wawasan terhadap kelayakan buku teks dari aspek kebahasaan, isi, dan aspek-aspek lainnya.

\section{DAFTAR PUSTAKA}

Firdaus, A., Sahmati, S., dan Suyanto, Edi. (2014). “Analisis Kelayakan Isi Buku Teks Bahasa Indonesia Terbitan Erlangga Kelas VII SMP/MTs". Jurnal Kata (Bahasa, Sastra, dan Pembelajarannya), 4 (2), hal. 112. Diperoleh dari https://eric.ed.gov/?journals (diunduh 12 Februari 2016).

Handayani, Conny, Bernadus Wahyudi Joko Santoso, dan Diah Vitri Widayanti. (2011). "Tindak Tutur Direktif Dosen dengan Tenaga Administrasi: Ancangan Sosiopragmatik Berperspektif Jender". Lingua, 7 (2), hlm. 56-63. Diperoleh dari http://journal.unnes.ac.id/sju/index.php/lingua (diunduh 13 Agustus 2017).

Ida, Rahma. (2001). Analisis Isi Kualitatif: Ragam Penelitian Isi Media Kuantitatif dan Kualitatif. Jakarta: Grafindo.

Kriyantono, Rachmat. (2007). Teknik Praktis Riset Komunikasi. Jakarta: Kencana Prenada Media Group.

Lestari, Retno Dwi, Mimi Mulyani, dan Subyantoro. (2016). "Pengembangan Model Pembelajaran Induktif dengan Media Gambar Seri yang Bermuatan Nilai Karakter untuk Meningkatkan Kompetensi Menulis
Paragraf Peserta Didik Kelas III". Lingua, XII (1), hlm. 53-62. Diperoleh dari http://journal.unnes.ac.id/sju/index.php/lingua (diunduh 13 Agustus 2017).

Lule, Esra. (2013). “An Application Example Related With Lexical View of Turkish Lesson and Study Books". TSA/YIL $17 \mathrm{~S}$, page 151-168. Diperoleh dari https://eric.ed.gov/?journals (diunduh 12 Februari 2016).

Maryanto, Muslikah, A., Wahyuni, D., dan Hayati, N. (2015). Bahasa Indonesia Ekspresi Diri dan Akademik SMA/MAK Kelas XII Semester 1. Jakarta: Kemendikbud.

Moleong, Lexy J. (2007). Metodologi Penelitian Kualitatif. Bandung: remaja Rosdakarya.

Riyanto, Agus. (2013). "Pengembangan Buku Pengayaan Keterampilan Membaca Bahasa Indonesia yang Bermuatan Nilai Kewirausahaan”. Seloka, 2 (1), hlm. 27-32. Diperoleh dari http://journal.unnes.ac.id/sju/index.php/seloka (diunduh 13 Agustus 2017).

Yurtseven, Nihal dan Mehtap Bademcioglu. (2016). "Teachers Professional Development: A Content Analysis about the Tendencies in Studies". Journal of Education and Training Studies, Vol. 4, No. 6. Turkey: Yildiz Technical University. Diperoleh dari https://eric.ed.gov/?journals (diunduh 2 Oktober 2017).

Abed, Eman Rasmi dan Mohammad Mustafa Al-Absi. (2015). "Content Analysis of Jordanian Elementary Textbooks during 1970-2013 as Case Study". International Education Studies, Vol. 8, No. 3. Canada: Canadian Center of Science and Education. Diperoleh dari https://eric.ed.gov/?journals (diunduh 2 Oktober 2017).

Dirlikli, Murat, Kamil Aydın, dan Levent Akgün. (2016). "Cooperative Learning in Turkey: A Content Analysis of Theses". Educational Sciences: Theory \& Practice, Vol. 16, No. 4. Turkey: Siirt University. Diperoleh dari https://eric.ed.gov/?journals (diunduh 2 Oktober 2017). 